\title{
KUR’ÂN KISSALARININ ANLAŞILMASINDA DUANIN ROLÜ
}

Mehmet Nurullah AKTAŞ*

\section{$\ddot{O} z$}

Kısasu'l-Kur'ân (Kur'ân Kıssaları), Kur'ân-1 Kerîm'in anlaşılmasında önemli rolü olan ilimlerden biridir. Kur'ân-1 Kerîm'de verilmek istenen ahlâkî ve eğitsel mesajlar, genellikle kıssalar vasitasıyla muhataplara iletilmektedir. Bu kıssalar, Kur'ân-1 Kerîm'de farklı yerlerde ve değişik vesilelerle zikredilmektedir. Kıssalarda yer alan önemli hususlardan biri de duadır. Dua, Hz. Âdem'den (a.s.) itibaren insanların gündeminde olan ve farklı mevzuları içerisinde barındıran iletişim kanallarından biridir. Bu çalışmada, peygamberlerden Hz. Şuayb (a.s.) ve Hz. Mûsâ (a.s.) kıssası, Câlût'a karşı mücadele veren Tâlût kıssası ile Âl-i İmrân 3/146-147. âyetlerde zikredilen ve peygamberlerin safında mücadele eden ribbiyyûn kıssası ve bu kıssalarda zikredilen dualar esas alınacaktır. Örnek olarak seçilen bu dört kıssadan hareketle, ilgili kıssaların anlaşılmasında duaların rolü incelenecektir. Makalenin amacı, kıssalarda geçen duaların Kur'ân kıssalarının anlaşılmasına katkısını incelemek, bu vesileyle muhataplara verilmek istenen mesajları tespit etmeye çalışmaktır.

Anahtar Kelimeler: Kur'ân kıssaları, dua, Hz. Mûsâ, Hz. Şuayb, Tâlût, ribbiyyûn.

\section{THE ROLE OF PRAYER IN UNDERSTANDING OF THE QUR'ANIC STORIES}

\begin{abstract}
Qasas-ul-Qur'an (The stories of the Qur'an) is one of the science that is effective in understanding the Holy Qur'an. The messages moral and educational to be given in the Holy Qur'an are usually transmitted to the addresses through the story. These stories is mentioned in different places by different occasions in the Qur'an. One of the most important subject which is taken place in these stories is pray. Pray which contains different subject and engages people's agenda has been the one of the communication way since Prophet Adam. In this study, the role of the prayers in the understanding of the Qur'anic shorts will be examined. In this study, story of Prophet Shuayb and story of Prophet Moses and story of Tâlût (Saul) and story of Ribbiyyûn fought alongside the prophets in the Al-i Imran 3/147 will be discussed. Those four examples chosen will examine the role of prayers in understanding the short stories. The aim of the study is to examine the contribution of the prayers in the understanding of the Qur'anic stories, in addition to determine the messages of the stories to the Muslims.
\end{abstract}

Keywords: The Qur'anic stories, prayer, Prophet Shuayb, Prophet Moses, Tâlût (Saul), ribbiyyûn.

Makale Gönderim Tarihi: 27.05.2018, Kabul Tarihi: 16.08.2018

Doi: $10.26791 /$ sarkiat.427482

* Dr. Öğr. Üyesi, Batman Üniversitesi İslami İlimler Fakültesi, Tefsir Ana Bilim Dalı, m.nurullahaktas@hotmail.com.

ORCID ID: 0000-0003-0854-3942 


\section{Giriş}

Kur'ân kıssaları, hacim olarak Kur'ân'ın önemli bir kısmını teşkil eden ve verilmek istenen mesajların muhataplara sağlıklı bir şekilde ulaşmasını sağlayan Kur'ânî ilimlerden biridir. Hidayet olarak nâzil olan Kur'ân-1 Kerîm, tarihte vuku bulmuş hâdiseleri ve kıssaları hatırlatmakta, bunlardan çıkarılacak derslerle yarınları inşa etmenin ehemmiyeti üzerinde durmaktadır. Kıssalar, her ne kadar görünüşte peygamberlerin ve diğer bazı kimselerin mücadelelerinden kesitler anlatıyor olsalar da kullanılan anlatım üslubu, her defasında Muhammedî davetin bir aşamasına da işaret etmekte ve ona uygun düşmektedir. ${ }^{1}$

Hacim olarak kıssalar kadar olmasa da Kur'an'da geçtiği yerleri dikkate aldığımızda azımsanmayacak bir kemiyete sahip olan diğer bir Kur'an ayetleri grubu dualardır. Okuyucuyla somut bir ilişkiyi kurmak açısından Kur'an kıssaları ile Kur'an dualarının benzer bir yöne sahip olduğu söylenebilir. Aralarındaki bu benzerliği toplumsal satıhta da görmek mümkündür. Nitekim günümüzde en çok satılan ve okunan dinî kitapların başında dini hikâyelerin yanı sıra dua kitapları gelmektedir. Bu konuda yapılmış pek çok çalışma, genel olarak duaları okumanın fazileti ile ilgili eserler olduğu görülmektedir. ${ }^{2}$ Toplumun dikkatini çeken bu konu ile ilgili sağlıklı bilgiye ve ilgili duaların bağlamını anlamaya ihtiyaç duyulduğu bir gerçektir. Zira Kur'ân-1 Kerîm, her türlü dış tesirden uzak bir şekilde farklı ruhlar üzerinde hayranlık bırakıcı tesirini icra edebilmişse, bunun sebebi, onun, insanların karşısına duygu ve düşüncelerine uygun düşen, inanç ve hareketlerine cevap veren ve kafalarını kurcalayan büyük meselelere çözüm getiren, kendine has bir üslûb ile çıkmış olmasıdır. ${ }^{3}$

Ehemmiyetinden dolayı dualar üzerine azımsanmayacak çalışmalar yapılmıştır. Ancak bu eserlerin ya genel olarak dua konusunu ele aldıklarını ${ }^{4}$ ya da genel anlamda Kur'an'daki duaları ele aldıklarını ${ }^{5}$ görmekteyiz. Oysa daha da özel olarak Kur'an kıssalarında geçen duaları ve bu duaların kıssanın anlaşılmasındaki rolünü müstakil olarak ele almanın konun farklı bir yönünü ortaya koyabileceğini düşünmekteyiz.

Bu makalemizde meselenin anlaşılması sadedinde Hz. Şuayb ile Hz. Mûsâ'nın kıssalarının yanında Câlût ile mücadele eden Tâlût kıssası ile Al-i İmrân 3/146-

\footnotetext{
${ }^{1}$ Mahmut Ay, Kur'ân Klssalarını Sîret Bağlamında Okumak, Ensar Yay., İstanbul 2017, s. 92-93.

${ }^{2}$ Ali Akpınar, Peygamber Dualarl, Serhat Kitapevi, 5. Baskı, Konya 2009, s. 14.

${ }^{3}$ Abdullah Draz, Kur'ân'a Giriş, Kitâbiyât Yay., Ankara 2000, s. 57.

${ }^{4}$ Suleyman b. Ahmed Taberî, Kitâbu'd-Du 'â, Dâru'l-Hadîs, Kâhire 1428/2007; Yahya b. Şeref enNevevî, el-Ezkâr, Dâru'l-Feyhâ', Dimaşk 1438/2017; Muhammed Şihâbuddin, Levâmi 'u'l-Envâr fi'l-Ed'iye ve'l-Ezkâr, Dâr İbn Hazm, 1437/2016; Muhammed Gazzâlî, Fennu'z-Zikr ve'd-Du'â, Dâru'ş-Şurûk, Kâhire 2014; Târık b. 'Atıf Hicâzî, el-Câmi'u'l-'Âmme fi'l-Ed 'iyye ve'l-Ezkâr, Dâru'l-Mevedde, Kâhire 1435; Ali Pekcan, Dualar ve Zikirler, Ek Kitap Yay., İstanbul 2012.

${ }^{5}$ Mehmet Halîl Çiçek, Durûsu'l-Ed 'iyyeti'l-Kur'âniyye, Dâr el- Kutubi'l-'İlmiyye, Beyrût 2013; Atilla Yargıc1, Kur'ân'da Dua, İltek Yay., İstanbul 2017; Kayıklık, “Kur'ân'daki Dualar Üzerine Psikolojik Bir Değerlendirme”, Çukurova Üniv. Ilahiyat Fak Dergisi, S.1, C. 1, s. 136, 2001; Saliha Bilgiç, Konuları İtibarı Ille Kur'an'da Dua, Selçuk Üniversitesi Sosyal Bilimler Enstitüsü, Yayınlanmamış Yüksek Lisans Tezi, Konya, 2008; Hidayet Ayan, Kur'ân'da Peygamber Duaları Ve Dîn̂ Kültürümüzdeki Yeri, Marmara Üniversitesi Sosyal Bilimler Enstitüsü, Yayınlanmamış Yükseklisans Tezi, İstanbul 2009; Abdullah Ertuç, Kur'an'da Dua Kavramının Din Eğitimi Açısından Tahlili, Süleyman Demirel Üniversitesi Sosyal Bilimler Enstitüsü, Yayınlanmamış Yüksek Lisans Tezi, 2012 Isparta.
} 
147. âyetlerde zikri geçen ve hakkın tarafını seçerek mücadele eden ribbiyyûn kıssası incelenecektir. Bu dört örnekten hareketle duanın Kur'ân kıssalarının anlaşılmasındaki ehemmiyetini anlamak mümkün olacaktır.

\section{Dua Kavramı ve Bağlam}

Dua, "isimlendirmek, seslenmek, istemek, yardım talep etmek" manalarına gelmektedir. ${ }^{6}$ Istılahî olarak da Allah'ın yüceliği karşısında kulun aczini itiraf etmesi, sevgi ve ta'zim duyguları içinde lütûf ve yardımını dilemesi ${ }^{7}$ anlamlarını ifade etmektedir. İbn Manzûr'a göre Allah'a hamdü senâ etme, Allah'tan af, merhamet, yardım isteme ve Allah'tan dünyevi nimetleri talep etme ${ }^{8}$ ş̧eklinde üç çeşit dua bulunmaktadır.

İzutsu (ö. 1993), duanın yapı bakımından vahye benzediğini, ancak duada konuşma doğrultusunun yukarıdan aşağıya doğru değil, aşağıdan yukarıya doğru olduğunu belirtmektedir. ${ }^{9}$ Açıklamasının devamında İzutsu şunları kaydetmektedir: "Allah, âyetlerini indirdiği zaman insanın bunlara ya 'tasdik' veya 'tekzib' şeklinde cevap vermesini ister. Tıpkı bunun gibi insanın dua hareketi de Allah tarafından cevaplandırılmak ister. Başka deyişle insan, arzusunun kabul edilmesi amacıyla Allah'a yalvarır. Allah'ın insanın yaptığı duaya cevap verişine Kur'ân'da isticâbe denmiştir ki 'cevap verme', 'cevaba hazır olma' demektir." 10

Duanın hedefi insanın Allah'a halini arz etmesi, O'na niyaz ve yakarışta bulunmasıdır. Bu yönüyle dua, kul ile Allah arasında vuku bulan özel bir diyalog olup hiçbir vasıtaya ihtiyaç duymamaktadır. ${ }^{11}$ Dolayısıyla iletişim kanallarından birisi olan dua ile insan, doğrudan doğruya Allah'a başvurmakta ve O'nunla konuşmaktadır. $^{12}$

Kur'ân'daki dualar, duasız dinsel bir yaşayışın olamayacağı fikrini vermektedir. ${ }^{13}$ Zira Kur'ân dualarının içeriğine bakıldığında bunların neredeyse hayatın her alanına dokunduğu ve Kur'ân'ın içeriğiyle paralellik gösterdiği anlaşılmaktadır. Duaların içeriğini tevhid, ${ }^{14}$ nübüvvet, ${ }^{15}$ âhiret, ${ }^{16}$ ibadet, ${ }^{17}$ ahlâk, ${ }^{18}$ adalet, ${ }^{19}$ şükür, ${ }^{20}$ sâlih bir nesil, ${ }^{21}$ yardım isteme, ${ }^{22}$ tövbe etme ve af dileme ${ }^{23}$ gibi başlıklar altında

${ }^{6}$ Râğib el-İsfehânî, el-Mufredât fî Ğarîbi'l-Kur'ân, Thk: Muhammed Seyyid Keylânî, Dâru'lMa'rife, Beyrut trs. s. 170; Osman Cilacı, “Dua”, DIA, Türkiye Diyanet Vakfı yayınları, İstanbul 1995, IX, 529.

${ }^{7}$ Cilac1, "Dua", IX, 529.

${ }^{8}$ İbn Manzûr, Lisânü'l- 'Arab, “De 'â" md, s. 1385.

${ }^{9}$ Toshihiko Izutsu, Kur'ân'da Allah ve İnsan, çev. Süleyman Ateş, Kevser Yay., Ankara ts, s. 182.

${ }^{10}$ Izutsu, Kur'ân'da Allah ve İnsan, s. 184.

${ }^{11}$ Ahmet Akbaş, Kur'ân'da İnsanın Mutluluğu, Rağbet Yayınları, İstanbul 2015, s. 301.

${ }^{12}$ Hayati Hökelekli, Din Psikolojisi, TDV Yay, Ankara 1996, s. 213.

${ }^{13}$ Hasan Kayıklık, “Kur'ân'daki Dualar Üzerine Psikolojik Bir Değerlendirme”, Çukurova Üniv. Illahiyat Fak Dergisi, S.1, C.1, 2001, s.136.

14 İbrâhîm 14/38; Tâhâ 20/35; Enbiyâ 21/87; Mü'min 40/7; Nûh 71/13.

${ }^{15}$ Kehf 18/1; Tâhâ 20/134; Furkân 25/30.

${ }^{16}$ Şu'arâ 26/87-88; Furkan 25/65-66; Mü’min 40/8.

17 İbrâhîm 14/40.

${ }^{18}$ Yûsuf 12/33; Neml 27/19.

${ }^{19}$ A'râf, 7/89; Enbiyâ 21/112; Şu'arâ 26/118.

${ }^{20}$ Neml 27/19; Ahkâf 46/15.

${ }^{21}$ Meryem 19/5; Furkan 25/74; Ahkâf 46/15.

${ }^{22}$ Mâide 5/25; Mü'minûn 23/26, 39; Kamer 54/10.

${ }^{23}$ A'râf, 7/149, 151; Şu'arâ 26/86; Nûh 71/28. 
toplamak mümkündür. Ali Şeriati (ö. 1977), duaların sadece dua olmadığını Allah'a hitap etme kalıbında, insanın isteklerini ve ihtiyaçlarını bildirme şeklinde felsefî ve itikadî birer eğitim ve öğretim metni ${ }^{24}$ olduklarını ifade etmektedir.

Yukarıda aktarılan bilgilerden kıssa-dua ilişkisini açıklayabilmek için bağlam veya context olarak da ifade edilen siyâk-sibâk meselesinin dikkate alınması gerektiği açıkça anlaşılmaktadır. Bağlamın tefsîr açısından önemi, Kur'ân'ın temelde dilsel bir hitap oluşundan kaynaklanmaktadır. ${ }^{25}$ Her ne kadar Kur'ân'ın indiği dönemde yaşayan insanlar için bir anlam sorunundan bahsetmek mümkün değilse de sonraki dönemlerde gelen muhataplar için, arkasında sözlü hitabın veya sözlü dil kullanımının var olduğu yazılı bir metin vardır. Bu yazılı hitabın anlaşılabilmesi için metin dışı bağlama ihtiyaç vardır. Sözün oluştuğu ortamın deşifre edilmesi ve metnin sözün bağlamına yerleştirilmesi gerekmektedir. ${ }^{26}$ Buradan hareketle Kur'ân'da zikredilen duaları bağlamı ile birlikte değerlendirmeye ihtiyaç bulunduğu anlaşılmaktadır.

Anlama faaliyetinin sağlıklı gerçekleşebilmesi sürecinde ilgili ifadenin kullanıldığ 1 metin içindeki yeri, öncesi ve sonrası ile bağlantısı, hangi ortam ve koşullarda ortaya çıktığı bilinmelidir. ${ }^{27}$ Zira Kur'ân'da zikredilen âyetlerin bağlamı dikkate alınmadan yapılan yorumlar, ciddi anlama sorunlarına sebep olmaktadır. Meselâ Tevbe sûresinin tefsirinde Sa'lebe kıssası zikredilmektedir. Birçok tefsirde rivâyet edilen bu kıssa, ilgili âyetlerin bağlamı ihmal edildiğinden yanlış anlamalara yol açmaktadır. Zira söz konusu âyetlerin bağlamı, münafiklarla ilgili hususları içermektedir. ${ }^{28}$ Dolayısıyla âyetlerin bağlamı dikkate alınarak yapılan çalışmalar, yanlış anlamaların önüne geçmeyi ve ilahî murada uygun mana vermeyi sağlamaktadır. Bu durum kıssalarda zikredilen dualar için de geçerlidir.

Metin yorumunda bağlamı dikkate almak, İslamî ilimlerin hemen hepsinde göz önünde bulundurulan bir hususiyettir. ${ }^{29} \mathrm{Bu}$ çerçevede Kur'ân ve bağlam ile ilgili son dönemlerde önemli çalışmalar ${ }^{30}$ kaleme alındığı gibi hadis ve bağlam üzerine de kayda değer ilmî eserler ${ }^{31}$ ortaya konulmaktadır.

\footnotetext{
${ }^{24}$ Ali Şeriati, Dua, Fecr Yay., Ankara 2013, s. 69.

${ }^{25}$ Nihat Uzun, Bağlam ve Kur'ân'ın Anlaşılması Üzerine, Ankara Okulu Yay., Ankara 2016, s. 16.

${ }^{26}$ Süleyman Gezer, "Sözlü ve Yazılı Kültür Ayırımında Kur'ân”, İslâmî Ilimler Dergisi, Yı1:3, S.2, Güz 2008, s. 249.

27 İsmail Çalışkan, Tefsîr Usulü, Ankara Okulu Yay., Ankara 2017, s. 187; Halis Albayrak, Tefsîr Usulü, Şûle Yay., İstanbul 2011, s. 124-127.

${ }^{28}$ Ahmet Nedim Serinsu, Kur'ân ve Bağlam, Şule Yay., İstanbul 2012, s. 221.

${ }^{29}$ Muhammed Coşkun, Kur'ân Yorumunda Sîret-Nüzûl İlişkisi, Fikir Yay., İstanbul 2014, s. 32.

${ }^{30}$ Serinsu, Kur'ân ve Bağlam, s. 221; Dücane Cündioğlu, Kur'ân'’ Anlamanın Anlamı, Tibyan Yay., İstanbul 1995; Fatih Tiyek, Kur'an'ı Anlamada Bağlamın Rolü ve Meallerdeki Bağlamsal Sorunlar, Ankara Okulu Yay., Ankara 2015; Ay, Kur'ân Kıssalarını Sîret Bağlamında Okumak; Coşkun, Kur'ân Yorumunda Sîret-Nüzûl İlişkisi; Gezer, "Sözlü ve Yazılı Kültür Ayırımında Kur'ân; Aydın Temizer, Kur'ân Tefsîrinde Karine, İfav Yay., 2. Bask1, İstanbul 2016; Uzun, Bağlam ve Kur'ân'ın Anlaşılması Üzerine.

${ }^{31}$ bkz. Nurullah Agitoğlu, Hadis ve Bağlam, Kitâbî Yay., İstanbul 2015.
} 


\section{Kur'ân Kıssalarında Dua}

Kur'ân, en küçük parçasından, en büyük parçasına kadar fikri bir uyumluluğa ve bütünlüğe sahip olan ${ }^{32}$ bir kitaptır. Dikkatle ve önyargısız incelendiğinde onun kendisine has bir fikir örgüsüne sahip olduğu ve iletmek istediklerini, kendi kavram ve kalıplarıyla takdim ettiği görülmektedir. ${ }^{33} \mathrm{Bu}$, kıssaların üslûbuna ve kıssalarda zikredilen dualara da yansımaktadır. Zira kıssalar ve bu vesileyle zikredilen dualar, kendine özgü bir üslûp ile verilmek istenen mesajları muhataplara takdim etmektedir.

Kur'ân kıssalarının anlaşılmasında önemli rol oynayan etkenlerden birisi şüphesiz ki dualardır. Kıssalarda zikredilen duaların bu etkinliğini birçok açıdan fark etmek mümkündür. Bir yönüyle dualar, davetin herhangi bir aşamasını tasvir ettiği gibi davet üslûbunun, davette aksayan yönlerin veya davet serüveninin ipuçlarını da vermektedir.

Dua sınırlı, sonlu ve âciz olan varlığın, sınırsız ve sonsuz kudret sahibi ile kurduğu bir köprüdür. Kıssalara bu açıdan baktığımızda insanın, hiçbir zaman duadan uzak kalmadığını görürüz. ${ }^{34}$ Buradan hareketle Kur'ân-1 Kerîm'in, insanlığın dünyadaki eylemlerini dua ile başlattığını söylemek mümkündür. ${ }^{35} \mathrm{~Hz}$. Âdem (a.s.) ile Havva'nın, "Rabbimiz! Biz kendimize zulüm ettik. Ĕger bizi bağışlamaz ve bize acımazsan mutlaka ziyan edenlerden oluruz."36 ifadesindeki tövbe ve niyazı buna delil olarak zikredilebilir.

Kıssaların, âyetlerin nüzûl zamanı ve nüzul ortamı ile doğrudan ilişkisi vardır. Her kıssasının indiği ortamı ve arka planı tetkik edildiğinde Hz. Muhammed'i (s.a.s.) veya sahabileri teselli ettiği, onların azimlerini güçlendirdiği ya da inkârcıları tehdit ettiği görülmektedir. Kur'ân'da anlatılan peygamber kıssaları, risâlet görevinin ne kadar meşakkatli olduğunu gözler önüne sererken Hz. Muhammed'in (s.a.s.) ve ashabının içine düştügü stres, kaygı ve üzüntülerin, çektikleri sıkıntıların da risâlet görevi ve imtihanından başka bir şey olmadığını vurgulamaktadır. Vahiy-olgu ilişkisinden de anlaşıldığı üzere, onları teskin etmek, stres ve psikolojik çöküntüden kurtarmak, teselli etmek ve onlara moral vermek için kıssa muhtevalı âyetler ve sûreler nâzil olmuştur. Başta Hz. Peygamber olmak üzere inananlar, sıkıntı ve bunalımlar karşısında bilinçlenmiş, azim ve kararlılık göstererek başarının yollarını aramış ve ümitsizlik girdabına kapılmamışlardır. ${ }^{37}$

\subsection{Hz. Şuayb (a.s.) Kıssası ve Dua}

Hz. Şuayb kıssas1, ayrıntılı bir şekilde A'râf (85-93), Hûd (84-95), Şu'arâ (176191) ve 'Ankebût (36-37) sûrelerinde zikredilmiştir. Ele alacağımız duanın geçtiği A'râf sûresi, nüzul sırasına göre Sâd sûresinden sonra nâzil olmuştur. ${ }^{38}$

\footnotetext{
${ }^{32}$ Halis Albayrak, Kur'ân'ın Bütünlüğü Üzerine, Şule Yay., 1996, s. 47.

${ }^{33}$ Albayrak, Kur'ân 'ın Bütünlüğ̈̈ Üzerine, s. 73.

${ }^{34}$ Cilac1, "Dua", IX, 529.

35 Edip Çağlar, "Araplarda Dua ve Yaygın Olarak Kullanılan Duaların Belâ̆gat Açısından Değerlendirilmesi”, D.E. Ü. Illahiyat Fakültesi Dergisi, S. XVIII, s. 171, İzmir, 2003.

${ }^{36}$ A'râf, 7/23.

37 Çalışkan, Tefsîr Usulü, s. 133-134; Abdurrahman Ensari, el-Mürşidü'l-Veciz İla Ulûmi’lKur'ani'l-Aziz, Nida Yayıncilık, İstanbul 2016, s. 234-235.

${ }^{38}$ Muhammed et-Tahir İbn 'Âşûr, et-Tahrîr ve't-Tenvîr, Dâr Suhnûn, Tûnus ts, VIII/2, 6-7; Muhammed 'Âbid Cabirî, Fehmu’l-Kur'ân, Dâru’n-Neşril-Mağribî, Mağrib 2008, I, 208.
} 
Peygamber kıssalarının en yoğun zikredildiği sûrelerden olan bu sûre, ${ }^{39}$ aynı zamanda Mekkî sûrelerin en uzun olanıdır. ${ }^{40}$ Sûrede zikredilen mevzular ve sûrenin genel üslûbu bu sûrenin Mekke döneminin son yıllarında Medine'ye hicretten evvel nâzil olduğu izlenimini vermektedir. ${ }^{41}$ Kavmini tek olan Allah'a inanmaya davet eden Hz. Şuayb (a.s.), ${ }^{42}$ toplumdaki yozlaşmaya ve yaygınlaşan haksızlıklara karşı uyarıları yapmıştır. ${ }^{43} \mathrm{O}$ da diğer peygamberler gibi yalancılıkla itham edilmiş, ${ }^{44}$ bununla yetinmeyen Medyen halkı onu sürgün etmek ${ }^{45}$ hatta öldürmekle ${ }^{46}$ tehdit etmiştir. Yapılan uyarılardan ders çıkarmayan ve $\mathrm{Hz}$. Şuayb'in (a.s.) dâvetine icabet etmek yerine hakkı ortadan kaldırmak için değişik yollara başvurmaktan kaçınmayan Medyen halkının helâk edildiği ${ }^{47}$ ifade edilmiştir. Buna göre A'râf sûresinde, bir yandan Müslümanlara öz yurtlarından çıkarılabilecekleri haber verilmiş, diğer yandan inanmayanlara, inananları yurtlarından çıkaranların akıbetinin yok olmak olduğu hatırlatılmıştır. ${ }^{48}$

Bu mücadele sürecinde Hz. Şuayb (a.s.), Yüce Allah’a şu şekilde yakarmıştır:

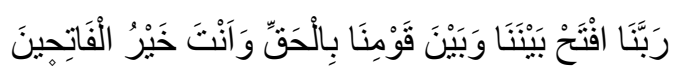

\section{“Ey Rabbimiz! Bizimle kavmimiz arasında gerçekle hükmet. Çünkü sen} hükmedenlerin en hayırlısisin." "49

İbn Abbâs, Hasan, Katade ve Süddî, duada zikredilen "iَْْiْ / ifteh" ifadesinin "karar ver ve hüküm ver" manasına geldiğini ifade etmektedirler. ${ }^{50}$ Ferrâ'ya (ö. 207/822) göre Umman halkı, hakkın önünü açtığ1 ve hakça karar verdiği için hâkime fâtih, fettâh adını vermektedirler. ${ }^{51}$ Muhammed Esed (ö. 1992), ilgili âyete "Ey Rabbimiz! Bizimle kavmimiz arasında hak neyse, ortaya çıkar." şeklinde mana verdikten sonra feteha lafzının "karar verdi" anlamına da gelebileceğini, bununla birlikte burada, kimin haklı olduğuna dair zihninde herhangi bir şüphe olmaması nedeniyle Hz. Şuayb'in duasının Allah'ın "kararı"na ilişkin bir dileği dile getirmediğini ifade etmektedir. ${ }^{52}$

Duadaki feth kelimesinin manası ile ilgili olarak İbn Abbâs'tan gelen başka bir rivâyette ise şu bilgiler yer almaktadır: "Âyette geçen "feth" kelimesinin hangi manaya geldiğini bilmiyordum. Fakat falan kabileden bir kadınla evlenince aramızda aile içi sorunlar baş gösterdi ve تعال حتى أفاتحك إلى فلان Buyur gel, falan kişi aramızda hakem olsun ifadesini kullandı. O zaman mufâtehe lafzının

\footnotetext{
${ }^{39}$ Mehmet Sait Şimşek, Hayat Kaynă̆ı Kur'ân Tefsiri, Beyan Yay., İstanbul 2012, II, 248.

${ }^{40}$ Muhammed İzzet Derveze, et-Tefsîru'l-Hadîs, Dâru'l-Ğarbi'l-İslâmî, Beyrût 2000, II, 361.

${ }^{41}$ Ebu'l-A'lâ Mevdudi, Tefhimu'l-Kur'ân, çev: Kurul, İnsan Yay., İstanbul 1991 II, 7; Şimşek, Hayat Kaynăğ Kur'ân Tefsiri, II, 248-249.

${ }^{42}$ A'râf, 7/85.

${ }^{43}$ Hûd, 11/84-87; Şu'arâ 26/176-184.

${ }^{44}$ A'râf, 26/176; Şu'arâ 26/189.

${ }^{45}$ A'râf, 7/88.

${ }^{46}$ Hûd $11 / 91$.

${ }^{47}$ Hûd, 11/94.

${ }^{48}$ Şimşek, Hayat Kaynă̆ı Kur'ân Tefsiri, II, 302.

${ }^{49}$ A'râf, 7/89.

${ }^{50}$ Fahruddîn er-Râzî, Mefâtîhu'l-Ğayb: et-Tefsîru'l-Kebîr, Dâru'l-Hadîs, Kahire 1433/2012, VII, 375.

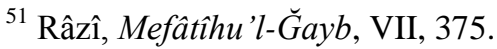

${ }^{52}$ Muhammed Esed, Kur'an Mesajl, çev: heyet, İşaret Yay., İstanbul 1999, I, 290.
} 
muhâkeme manasına geldiğini öğrenmiş oldum."53 İbn Abbâs’tan gelen bu rivâyetten işin içinden çıkılmaz hâle geldiği ifade edercesine durumu Yüce Allah'a arz etmeye karar verildiğini anlamak mümkündür.

Hz. Şuayb'ın davetine mukabil Medyen halkının önde gelenleri, "Dürüstlük, doğruluk, ahlak ve iyilik gibi hususları temel ilkeler olarak kabul eder ve uygularsak, biz o zaman tümüyle mahvoluruz." diyerek halkı kandırmak istemişlerdir. ${ }^{44}$ Burada dile getirilen "mahvolma" korkusunun sadece Hz. Şuayb'ın kavmine özgü bir olay olmadığını ifade eden Mevdudi (ö. 1979) sözlerine şöyle devam etmektedir: "Sefih toplumlar, hak, doğruluk ve dürüstlük hakkında, her zaman aynı tedirginliği duymuşlardır. Yalan, üçkâğıtçılık ve ahlaksızlığa başvurmaksızın ticaret, siyaset ve diğer dünyevî işlerin yürütülmesinin imkânsız olduğu düşüncesi tarih boyunca bütün iflas etmiş toplumların görüşü olagelmiştir." 55

Kur'ân'da anlatılan Hz. Şuayb kıssası, Hz. Peygamber'in Mekke toplumu ile mücadelesini hatırlatmaktadır. Hz. Şuayb'ın kıssası ve bu kıssada zikredilen dua, Hz. Peygamber ve sahabe açısından bir teselli ve sabır niteliğinde iken Mekke şirk toplumu açısından da ciddi bir uyarıyı içermektedir. Buradan hareketle başta Hz. Muhammed (s.a.s.) olmak üzere ilk Müslümanlar, Hz. Şuayb gibi nasıl teselli bulup mücadele azimleri pekişmişse, diğer Müslümanların da bu kıssalardan ders çıkarmaları, onlarla teselli bulmaları ve mücadelede ümitsizliğe kapılmamaları gerekir. Çünkü Allah'ın varlıklar hakkındaki yasası hiçbir zaman değişmeyecektir. ${ }^{56}$

Kavmi ile kurduğu iletişim bakımından peygamberlerin hatibi (hatîbu'l-enbiyâ) olarak nitelenen Hz. Şuayb, ${ }^{57}$ kavmini tevhid dinine davet edip gayri meşru ticarî ilişkilerini ve ticaretin sağlıklı yapılmasını sağlayan güvenliği ortadan kaldırıcı müdahalelerini eleştirdi. ${ }^{58}$ Medyen halkı, dünyevî işlerine ve günlük hayatlarına müdahale etmemesi şartıyla Hz. Şuayb'in ibadetlerini ifa etmesine ses çıkartmadıklarını da söylemek mümkündür. ${ }^{59} \mathrm{Bu}$ da peygamberlerin gönderiliş gayesi ile örtüşmediği gibi haksızlıklara karşı tepkisizliği peygamberlerden beklemek de mümkün değildir.

Kıssada zikri geçen dua ile Müslümanların toplumun ifsadına yol açan gelişmelere karşı gerekli uyarıları yaparak üzerlerine düşen görevi bihakkın yerine getirmeleri, bütün meşru metotları uyguladıktan sonra hakkın önünü açma ve çıkış yolu bulma namına meseleyi Allah'a arz etmek gerektiği anlaşılmaktadır. Kıssa bütünüyle değerlendirildiğinde kıssada zikredilen duanın kıssadaki rolünü anlamak mümkün olacaktır.

\footnotetext{
${ }^{53}$ Muhammed b. Muhammed Mâturîdî, Te 'vilâtu'l-Kur'ân, thk: Mecdî Bâsellûm, Dâru'l-Kutubi'lİlmiyye, IV, 505, Beyrût, 2005; Râzî, Mefâtîhu'l-ĞGayb, VII, 375.

${ }^{54}$ Mevdudi, Tefhimu'l-Kur'ân, II, 68.

${ }^{55}$ Mevdudi, Tefhimu'l-Kur'ân, II, 68.

${ }^{56}$ Abdulbaki Güneş, Kur'ân Kıssaları ve Medeniyetlerin İnşası, Gündönümü Yay, İstanbul 2005, s. 43.

${ }^{57}$ Nâsiruddîn 'Abdullah b. 'Omer eş-Şirâzî el-Beydâvî, Envâru't-tenzîl ve Esrâru't-Te'vîl, Dâru'lMa'rife, Beyrût, 1434/2013, s. 366; Muhammed Senâullah Mazharî, Tefsîru’l-Mazharî, Mektebetu Reşîdiyye, trs b.y., III, 59.

58 Hûd 11/84-86.

${ }^{59}$ Mevdudi, Tefhimu'l-Kur'ân, II, 418-419.
} 


\subsection{Hz. Mûsâ (a.s.) Kıssası ve Dua}

Farklı yerlerde ve bağlamlarda en çok zikredilen peygamber kıssası, Hz. Mûsâ kıssasıdır. Bu kıssada yeni doğan erkek çocukların katledilmesi kararından kurtulmak için yeni doğmuş olan Mûsâ'nın Nil nehrine atılması, ${ }^{60}$ genç Mûsâ'nın Misır'dan ayrılması ${ }^{61}$ ve Medyen'de Hz. Şuayb ile buluşması, ${ }^{62} \mathrm{~Hz}$. Mûsâ'ya Tevrat'ın nâzil olması ve peygamber olarak görevlendirilmesi, ${ }^{63}$ sihirbazların mümin oluş süreci ${ }^{64}$ ve Firavun'ın denizde boğulması ${ }^{65}$ gibi birçok konu yer almaktadır. Bunlardan bir kısmı Mekke döneminde bir kısmı da Medîne döneminde nâzil olmuştur. Mekke döneminde nâzil olan âyetler, Hz. Peygamber ile Mekke şirk toplumu arasındaki mücadele bağlamında Hz. Mûsâ ile Firavun arasındaki mücâdeleyi anlatmaktadır. Medîne döneminde nâzil olan âyetlerde ise Hz. Muhammed (s.a.s.) ile Müslümanlar arasındaki iletişim merkezli konular bağlamında Hz. Mûsâ ile İsrailoğulları arasında vuku bulan hâdiseler aktarilmaktadir.

Kur'ân-i Kerîm'e göre Mısır'dan ayrılıp Medyen'e gitmek zorunda kalan ve firari durumuna düşen ${ }^{66} \mathrm{~Hz}$. Mûsâ'nın tekrar Mısır'a dönmesi ve yaptığı zulümlerle tarihe geçen Firavun'un karşısına çıkıp hakkı haykırması ${ }^{67}$ istenmektedir. Hz. Mûsâ'nın, Firavun'un karşısına çıkıp hakkı ve hakikati anlatmadan evvel yaptığı dua, kıssanın seyrini ve meselenin ciddiyetini açıkça ortaya koymaktadır:

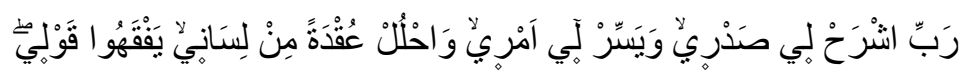

“Rabbim! Gönlüme ferahlık ver. Işsimi bana kolaylaştır. Dilimdeki tutukluğu çöz ki sözümü anlasinlar. "68

Yukarıdaki duanın geçtiği Tâhâ sûrenin Hz. Peygamber'in Mekke hayatının son döneminde vahyedildiği ile ilgili iddialar bulunmakla birlikte risâletin altınc1 yılana kadar giden erken bir dönemde sahabe tarafından bilindiği anlaşılmaktadır. $^{69} \mathrm{~Hz}$. Ömer'in Müslüman olmadan önce nâzil olduğu ${ }^{70}$ ve Müslümanların Habeşistan'a hicret ettiği döneme denk geldiği ifade edilmektedir. ${ }^{71}$ Buna göre bu sûre, müşriklerin Müslümanlara baskılarının arttı̆̆ bir sırada indirilmiştir. Böylece müşriklere Firavun kadar güçlü olmadıkları ve onun bile hak dava karşısında yenilgiye uğradığı hatırlatılmakta, ${ }^{72}$ müşriklerin baskıları altında zor şartlarda yaşayan Müslümanların bu şartlara direnmeleri ögütlemektedir. ${ }^{73}$ Başka bir ifade ile Mûsâ kıssası, Hz. Peygamber için bir

\footnotetext{
${ }^{60}$ Tâhâ, 20/38-40; Kasas, 28/7-13.

${ }^{61}$ Kasas, 28/14-22.

${ }^{62}$ Kasas, 28/22-28.

${ }^{63}$ Kasas, 28/29-37.

${ }^{64}$ A'râf, 7/103-125; Yûnus, 10/79-81; Tâhâ, 20/60-76; Şu'arâ, 26/34-51.

${ }^{65}$ Kasas, 28/39-40; Yûnus, 10/90-92.

${ }^{66}$ Kasas, 28/22-28.

${ }^{67}$ Kasas, 28/29-37.

68 Tâhâ, 20/25-28.

${ }^{69}$ Esed, Kur'an Mesajı, II, 623.

${ }^{70}$ Muhammed b. Ahmed Kurtubî, el-Câmi 'li Ahkâmi’l-Kur'ân, Dâru'l-Fikr, Beyrût 1415/1995, VI, 85; İbn 'Âșûr, et-Tahrîr ve 't-Tenvîr, XVII, 180-181; Cabirî, Fehmu'l-Kur'ân, I, 278.

${ }^{71}$ İbn 'Âşûr, et-Tahrîr ve't-Tenvîr, XVII/, 180-181; Cabirî, Fehmu'l-Kur'ân, I, 278.

${ }^{72}$ Şimşek, Hayat Kaynă̆ı Kur'ân Tefsiri, III, 326.

73 Derveze, Muhammed İzzet, et-Tefsîru'l-Hadîs, Dâru'l-Ğarbi'l-İslâmî, Beyrût 2000, III, 186; Şimşek, Hayat Kaynă̆ı Kur'ân Tefsiri, III, 322.
} 
tesellidir. Müşrikler komplolar kurarak onu öldürmeye kalkışacak olsalar bile Allah'ın kendisini kurtaracağına bir işarettir. ${ }^{74}$

Yukarıdaki duada geçen "gönlüme ferahlık ver" ifadesinin “(Ey Muhammed!) Senin göğsünü açıp genişletmedik mi? Belini büken yükünü üzerinden kaldırmadık $m \imath$ ? "75 âyetinde de zikredildiği gibi sinenin inşirâhının, nübüvvet ve risâlet sorumluluğunun hafifletilmesi ve bu vazifeyi hakkıyla ifa etme olanağının talep edilmesi şeklinde anlaşılması mümkündür. Veya kâfïlerin yalanlamalarına karşın sinede daralma ve ortaya çıkacak hüzün şeklinde de anlaşılabilir. ${ }^{76}$ Kalbin inşirahı, kalbin yumuşatılması şeklinde de yorumlanmaktadır. Zira peygamberler bir ortamda iki zıt şeyle sınanmaktadır. Biri kavmin yalanlaması üzerine Allah için ortaya konulan buğz; diğeri ise yalanlamalarına karşılık gelecek azaptan dolayı oluşan merhamet. Bu iki zıt vasıf, peygamberlere hastır. Sinelerinin bu iki zıt vasfı taşıyacak kadar geniş olmasını Allah'tan talep etmiş olmaları mümkündür. ${ }^{77}$

Hz. Mûsâ'nın yapmış olduğu dua ile Hz. Peygamber'e hitaben nâzil olan "Andolsun, onların söyledikleri şeylerden dolayı göğsünün daraldığını biliyoruz.",78 âyeti birlikte değerlendirildiğinde benzer tecrübenin her iki peygamber tarafından da yaşandığı anlaşılacaktır. ${ }^{79}$

Firavun'a hakk1 anlatmakla görevlendirilen Hz. Mûsâ, Hz. Hârûn'u kendisine yardımcı olmak üzere Yüce Allah'tan talep etmiş ve bunu da "Ehlimden, kardeşim Harun'u bana yardımcı kıl." ${ }^{\text {,0 }}$ şeklinde açıkça ifade etmiştir. Benzer şekilde Hz. Peygamber (s.a.s.) şiddetin arttı̆̆ bir dönemde Hz. Ömer için de "Allah'ım, şu iki adamdan, Ebû Cehil ve Ömer b. Hattâb'tan, sana en sevimli olanı ile İslam'ı aziz kll." şeklinde dua ettiği rivayet edilmektedir. ${ }^{81} \mathrm{~Hz}$. Ömer'in Müslüman olması ile birlikte, Müslümanların ciddi manada güç kazandığı, davetin seyrini önemli ölçüde etkilediği hatta Hz. Peygamber'in sevinçten tekbir getirdiği ile ilgili bilgiler zikredilmektedir. ${ }^{82}$ Buradan hareketle Tâhâ sûresinde geçen ve Hz. Mûsâ'nın Hz. Hârûn için yaptığı dua ile -söz konusu sûrenin indiği dönemin şartlarını de göz önünde bulundurarak- Hz. Peygamber'in Hz. Ömer için yaptığı duayı, nüzûl-siret bağlamı çerçevesinde değerlendirmek mümkün görülmektedir.

Kur'ân-1 Kerîm, Hz. Mûsâ ve Hz. Harun'un Firavun'un kendilerine zarar vermesinden endişe ettiklerine de işaret etmektedir. ${ }^{83} \mathrm{Bu}$ konudaki diyalog şu şekilde gelişmektedir: “(Yüce Allah), "Firavun'a gidin. Çünkü o azmıştır. Ona yumuşak söz söyleyin. Belki ögüt alır yahut korkar.” (dedi). Mûsâ ve Harun, şöyle

\footnotetext{
${ }^{74}$ Şimşek, Hayat Kaynă̆ı Kur'ân Tefsiri, III, 332.

75 İnşirâh, 94/1-3.

${ }^{76}$ Mâturîdî, Te'vîlâtu'l-Kur'ân, VII, 277.

${ }^{77}$ Mâturîdî, Te'vilâtu'l-Kur'ân, VII, 277.

${ }^{78} \mathrm{Hicr}, 15 / 97$.

${ }^{79}$ Ay, Kur'ân Kıssalarını Sîret Bağlamında Okumak, s. 176. Ay, Mahmut, Kur'ân Kıssalarını Hz. Muhammed'in Kıssası Paralelinde Okumak, Kur'ân Nüzûlünün Medine Dönemi, X. Tefsir Akademisyenleri Buluşması, Kahramanmaraş 2013, s. 124.

${ }^{80}$ Tâhâ 20/29-30.

${ }^{81}$ Tirmizî, Menâkıb 18.

82 İhsan Süreyya Sirma, Müslümanların Tarihi, Beyan Yay., İstanbul 2016, II, 105-111.

${ }^{83}$ M. Osman Necati, Kur'ân ve Psikoloji, Fecr Yayınları, Çev: Hayati Aydın, Ankara 2017, s. 63.
} 
dediler: "Ey Rabbimiz! Şüphesiz biz, onun bize karşı aşırı davranmasından yahut azmasından korkuyoruz. " 84 İki kardeşin bu korkuyu hissetmelerini yadırgamamak ve tabii görmek gerekir. Zira insanların çoğu, kuvvetli, nüfuz ve kudret sahibi, serkeş ve zalim kişilerin kendilerine zarar vermesinden endişe etmektedirler. ${ }^{85}$

Firavun'un sergilediği yaşam tarzı ve karakter yapısı her zaman her yerde bulunabilecek tiptedir. Bu ve benzeri yaşam tarzları tarihin herhangi bir zaman dilimiyle sınırlı olmadığı gibi, yeryüzünün herhangi bir bölgesine de özgü değildir. ${ }^{86}$ Burada Hz. Mûsâ, Firavun'un şahsında bir yaşam tarzına ve karakter yapısına itiraz etmek üzere yola çıkmış ve bu duayı yapmıştır. Dolayısıyla bu duada dile getirilen kendisini rahat ifade edebilme, muhatabının kendisini doğru anlamasını özellikle isteme, işin zorluğunu dikkate alarak kolaylık sağlamayı talep etme hususları dile getirilen meselelerin ehemmiyetini ve muhatabin ortaya koyacağı fevrî tepkilere hazır olduğu mesajını da vermektedir. Bu da duanın kıssadaki rolünü ve ehemmiyetini gözler önüne sermeye katkı sunmaktadır.

Kıssada geçen dua, siyâk ve sibaktan müstakil olarak okunduğunda, dindar veya dinin temel esaslarını öğrenmek üzere bir araya gelen bir kitleye öğüt verilirken konuşmacının kendisini rahatça ifade edebilmesi için okuduğu sıradan bir dua olarak algılanır. Lâkin kıssadaki serüvene ve bağlamına bakıldığında $\mathrm{Hz}$. Mûsâ'nın, bu duayı Firavun'un karşısına çıkıp hakkı ve hakikati anlatmadan evvel yaptığı anlaşılmaktadır. Hz. Mûsâ'nın bu aşamada söz konusu duayı yapmasının ne kadar yerinde ve isabetli bir karar olduğunu daha sonra gelişen olaylardan anlamak mümkündür. Ayrıca bu dua, kıssasının seyrini ve meselenin ciddiyetini açıkça ortaya koymaktadır.

\subsection{Tâlût Kıssası ve Dua}

Hak ile batıl arasındaki mücadeleyi aktaran ve bir avuç muvahhidin azmini ortaya koyan kıssalardan birisi de Tâlût ile Câlût arasında vuku bulan hâdisedir. Kur'ân-1 Kerîm, Tâlût'un Câlût ile mücadelesini ve savaş meydanında mü'minlerin takınması gereken tavırları ayrıntılı olarak aktarmaktadır. ${ }^{87}$

Tâlût'un kimliği ile ilgili Kur'ân'da herhangi bir bilgi verilmemektedir. Tâlût'un Yüce Allah tarafından İsrailoğullarına sadece "melik" olarak seçildiği bilgisi yer almaktadır. Ayrıca onun peygamber seçilip seçilmediği hakkında ne Kur'an'da ne de hadislerde açık bir hüküm bulunmaktadır. Bu nedenle onun melik olarak tayin edilmesi, aynı zamanda peygamber olarak seçildiği anlamına gelmemektedir. ${ }^{88}$

İsrailoğullarının önde gelenleri, o dönemde yaşayan ancak Kur'ân'da ismi zikredilmeyen peygamberlerine başvurarak, kendilerine bir komutan tayin edilmesini ve Allah yolunda savaşmak istediklerini bildirmişlerdir. ${ }^{89}$ Ancak kendilerine savaş farz kılınınca, verdikleri söze rağmen -çok az sayıda Müslüman

\footnotetext{
${ }^{84}$ Taha, 10/43-46, s. 63.

${ }^{85}$ Necati, Kur'ân ve Psikoloji, s. 63.

${ }^{86}$ Şükrü Aydın, “Kur'an'a Göre Yahudiliğin Mısır Dönemi ve Bu Dönemdeki Bölge Halklarının Karakter Yapıları”, Uluslararası Sosyal Araştırmalar Dergisi, Cilt: 9, Sayı: 47, Aralık 2016, s. 1045.

${ }^{87}$ Bakara, 2/246-252.

${ }^{88}$ Mevdudi, Tefhimu'l-Kur'ân, I, 192.

${ }^{89}$ Bakara, 2/246.
} 
dışında -çeşitli bahaneler ileri sürerek savaşmaktan kaçınmışlardır. ${ }^{90}$ Mü’minler ise az sayıdaki nice toplulukların Allah'ın yardımı ile çok sayıdaki nice topluluklara galip geldiğini söyleyerek savaştan vazgeçmeyeceklerini açıklamışlardır. ${ }^{91}$

$\mathrm{Bu}$ kıssada dikkat çekici bir ayrıntı, Tâlût'un toplulukta disiplin eksikliği olduğunu hissetmesidir. Bundan dolayı Tâlût, cesur olanı, korkak olandan, yetenekli olanı yeteneksizden ayırt etmek istemiş ${ }^{92}$ ve müminlere cihadın zorluklarını hatırlatmıştır. ${ }^{93}$ Tâlût ve ona inananlar, gerekli hazırlıklarını yapmış, önemli bir imtihanı başarmış ve cephede yerini almış bir vaziyette şu özlü yakarışı yapmışlardır:

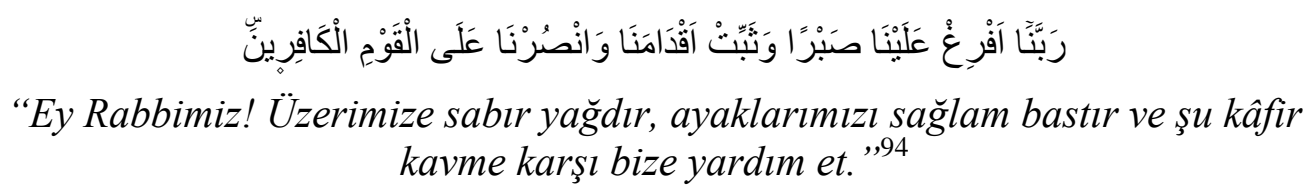

Üzerlerine düşen görevleri ifa ettikten sonra başka bir deyişle fiili duayı yaptıktan sonra gerçekleştirdikleri dua, onların Allah'a olan güven ve teslimiyetlerini göstermiştir. ${ }^{95} \mathrm{Bu}$ dua, aynı zamanda savaş esnasında mü'minlerin takınmaları gereken edebi de göstermektedir. ${ }^{96}$

Tâlût'un ordusu Câlût'un ordusuyla karşılaşıp kendilerinin azınlıkta, düşmanın ise çoğunlukta olduğunu görünce fetih ve yardımın ancak Allah'ın inayetiyle gerçekleşebileceğine inanmış, Yüce Allah'a dua ve tazarru ile meşgul olmuşlardı. Hz. Peygamber'in siretine bakıldığında onun da her yerde bu şekilde dua ettiği görülmektedir. Rivâyet edildiğine göre $o$, Bedir savaşında sürekli namaz kılmış ve Allah'tan vaadini yerine getirmesini talep etmiştir. ${ }^{97}$

Mü'minler bu dua ile hiçbir maddi hazırlık yapmadan oturdukları yerde miskince değil, aksine beşer gücü dâhilinde yapabileceklerinin en iyisini yaptıktan sonra güçlerini aşan noktada Allah'a yakarmışlardır. ${ }^{98}$ Dolayısıyla Tâlût kıssasında geçen bu dua, savaşın seyrini ve mü'minlerin durumu ile ilgili önemli detayları bizlere sunmuştur.

Bu duada yer aldığı gibi Kur'ân, sabır konusu üzerinde önemle durmakta ${ }^{99}$ ve çeşitli vesilelerle mü'minlerin sabretmesi gerektiğini hatırlatmaktadır. Zira Kur'ân, nefis terbiyesi açısından büyük faydası bulunan, düzgün kimlik kazanma potansiyeli barındıran, bu özelliğiyle muhataplarına zorluklara tahammül etme gücü veren, karşılaşılan problem ve zorluklara, zamanın sıkıntı ve musibetlerine karşı aktiviteyi yenileyen, Allah yolunda yapılacak cihadın zorluklarını

\footnotetext{
${ }^{90}$ Bakara, 2/246.

${ }^{91}$ Bakara, 2/251.

${ }^{92}$ Mevdudi, Tefhimu'l-Kur'ân, C. I, s. 195.

${ }^{93}$ Mevdudi, Tefhimu'l-Kur'ân, C. I, s. 190.

${ }^{94}$ Bakara, 2/250.

${ }^{95}$ Kerim Buladı, Dua 'nız Olmasaydı, Kayıhan Yay., İstanbul 2013, s. 129.

${ }^{96}$ Said Havva, el-Esas fi 't-Tefsîr, Dâru's-Selâm, 4. Tab', Kahire, 1993, I, 578.

${ }^{97}$ Râzî, Mefâtîhu'l-Ğeyb, III, 413; Güneş, Kur'ân Klssalarl ve Medeniyetlerin İnşasl, s. 115.

${ }^{98}$ Güneş, Kur'ân Kıssaları ve Medeniyetlerin İnşası, s. 115; Buladı, Dua'nız Olmasaydı, s. 127.

99 Bkz. "s.b.r." maddesi. Muhammed Fuad Abdulbaki, el-Mu'cemu'l-Mufehres li Elfâzi'lKur'âni'l-Kerîm, Dâru'l-Ma'rife, 2. Baskı, Beyrût, 1411/1991.
} 
omuzlamayı sağlayan bir sabır öğütlemektedir. ${ }^{100}$ Yukarıdaki duada üzerinde durulan “sabır" vurgusu, Tâlût'un yanında yer alan mü'minlerin duruşunu ve metanetini ortaya koymakta ve bundan gerekli dersleri çıkarmayı ehemmiyetli kılmaktadır. Hatta Mâturîdî (ö. 333/944), düşmanla karşılaşan herkesin bu şekilde dua etmesinin vacip olduğunu bildirmektedir. ${ }^{101}$ Bilindiği üzere sıkıntılı bir durumla karşılaşan enbiyâ ve sâlihlerin sünneti gereği Tâlût ve ona inanlar da Allah'a dua ile iltica etmişılerdir. ${ }^{102}$

Kur'ân-1 Kerîm, Tâlût'un şahsında topluma rehberlik edecek sağlam liderliğe ve onların arkasında saf duran inançlı insanlara tarih boyunca ihtiyaç olduğu mesajını vermektedir. $\mathrm{Bu}$ zaruretin günümüz Müslümanları için daha çok gerekli olduğu muhakkaktır. Malum oluğu üzere İsrailoğulları ile ilgili kıssaları farklı bağlamlarda zikreden Kur'ân-1 Kerîm, Müslümanların bu kıssalardan ders çıkarmaları ve aynı konuma düşmemeleri hususunda gerekli uyarıları yapmaktadır. Said Havva (ö. 1989), Tâlût kıssanın Filistin'deki müslümanların durumuna uygun düştüğünü ve bundan derslerin çıkarılması gerektiğini hatırlatarak şöyle demektedir: "Onlar kendi yurtlarından çıkarılıp çocuklarından, mallarından uzaklaştırıldılar. Bunun için onların yolu, liderlik ve cihattır. Mü'min bir lider ve mü'mince bir saf..."103 Tâlût, sorumluluğunun bilinci ile hareket eden vakur ve onurlu bir "melik/lider"; ona tabi olanlar da mü'minlere yakışan bir tavırla arkasında saf tutmayı beceren bir topluluk profilini çizmektedir. $\mathrm{Bu}$ karakterin, Hz. Peygamber (s.a.s.) ile sahabîler arasındaki ilişkilere de yansıdı̆̆ı açıkça görülmektedir.

Tarih boyunca haksızlığa karşı herkesin aynı tepkiyi vermesini veya hakkın tarafını tutmasını beklemek imtihan dünyasına aykırıdır. Tarihin her döneminde az sayıda da olsa hakkın tarafını tutan ve hakkı ayakta tutmak için canını ortaya koyan müminler var olmuştur. $\mathrm{Bu}$ dua, sayıları az da olsa inanan insanların peygamberlerinin mesajına sahip çıktığını ve hakkın tarafını tercih ettiğini aktarmaktadır. Bu da kıssadaki duanın söz konusu kıssanın anlaşılmasına katkısını ortaya koymaktadır.

\subsection{Ribbiyyûn Kıssası ve Dua}

Yüce Allah, Hz. Muhammed (s.a.s.) başta olmak üzere sahâbenin karşılaştığı sıkıntılara karşı dirençlerini pekiştirmek ve mücadele azimlerini arttırmak için önceki peygamberlerin başından geçenleri ve yaşadıkları deneyimleri Kur'ân'da zikretmektedir. ${ }^{104}$ Bunlardan biri de ribbiyyûn olarak nitelenen ve gönderildikleri dönemin peygamberlerini yalnız bırakmayıp, onların arkasında saf tutan mü'minlerin kıssasıdır. Bunu kıssa olarak nitelememize sevk eden âmil, Mâturî̀î’nin ilgili âyetlerin tefsirini yaparken "önceki ümmetlerin kıssaları..." şeklinde kullandığı ifadedir. ${ }^{105}$ Yüce Allah onları şu şekilde tavsif etmektedir:

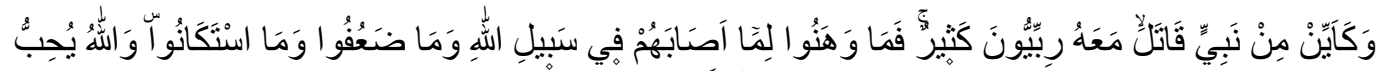

$$
\begin{aligned}
& \text { الصََّابِرِينَ }
\end{aligned}
$$

\footnotetext{
${ }^{100}$ Necati, Kur'ân ve Psikoloji, s. 269.

${ }^{101}$ Mâturîdî, Te 'vilâtu'l-Kur'ân, II, 229.

${ }^{102}$ Mazharî, Tefsîru'l-Mazharî, I, 341.

${ }^{103}$ Havva, el-Esas fi't-Tefsîr, I, 579.

${ }^{104}$ Güneş, Kur'ân Klssalarl ve Medeniyetlerin Inşası, s. 42.

${ }^{105}$ Mâturîdî, Te'vilâtu'l-Kur'ân, II, 501.
} 
"Nice peygamberler var ki, kendileriyle beraber birçok ribbiyyûn (peygamberleri yalnız bırakmayıp onların arkasında saf tutan mü'minler) çarpıştı da bunlar Allah yolunda başlarına gelenlerden yılmadılar, zaafa düşmediler, boyun eğmediler. Allah, sabredenleri sever.",106

Bu âyette geçen ribbiyyûn / ربيون kavram1, “ribbiyy/ ربي kelimesinin cem’i olup cemaat, topluluk manasına gelmektedir. ${ }^{107}$ Dil ve edebiyat âlimi İbn Fâris (ö. 395/1004) ise "ribbiyy" lafzının " العارف بالرب / rabbini tanıyan" anlamına geldiğini ifade etmektedir. ${ }^{108} \mathrm{Bu}$ bilgiler birlikte değerlendirildiğinde "ribbiyyûn" kelimesinin "Rabbini tanıyan topluluk" manasına geldiği anlaşılacaktır.

Haksızlıklara boyun eğmeyen, yılmadan ve zaafa düşmeden peygamberlerin safında mücadele eden ribbiyyûn mü'minler, şöyle dua etmişlerdir:

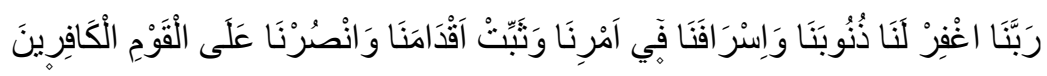

"Rabbimiz! Bizim günahlarımızı ve işimizdeki taşkınlıklarımızı bağışla ve (yolunda) ayaklarımızı sağlam tut. Kâfir topluma karşı bize yardım et "109

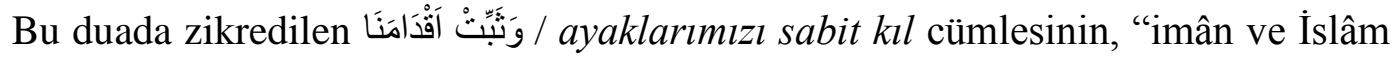
dini üzerinde sabit kıl” anlamına geldiği gibi "düşmanla karşılaşmada sabit kıl" anlamına da geldiği ifade edilmektedir. ${ }^{110}$ Nasr kelimesi ise "düşmanı delil ve burhanlarla yenme", "düşmanı güç ve kuvvetle yenme, hezimete uğratma" manalarına gelmektedir. ${ }^{111}$ Duada geçen zunûb lafzı da cem-i kesre sığası olup "günahlarının çokluğunu itiraf ederek Allah'a iltica etme ve tazarru ile yalvarma" manasını içermektedir. ${ }^{12}$ Âyette geçen israf ifadesinden "savaş esnasında gerekli tedbirleri almama veya düşmanla karşılaşmama" "113 "ubûdiyyet sınırını aşma" "114 gibi manaları anlaşılabildiği gibi hayatın akışı içerisinde oluşan yeme, içme, giyim, binek, mesken gibi bütün israf alanlarını kapsaması da mümkündür. ${ }^{115}$

Maturidî’ye göre Yüce Allah, yukarıda zikri geçen dua ile Muhammed ümmetine gerekli uyarıları yapmakta ve "Peygamberiniz size haber saldığında evvelki ümmetlerin kendi peygamberlerinin safında yer alacaklarına dair verdikleri ahit gibi sizin de aynı tavrı ortaya koymanız gerekmiyor muydu?"116 hususunu öğretmektedir. Buna göre peygamberleri katledilen mü'minlerin inançlarından taviz vermedikleri ve küfre boyun eğmedikleri hatırlatılmakta, katledilmesine rağmen peygamberlerinin davetini ve mücadelesini devam ettirdikleri ifade edilmekte, ${ }^{117}$ evvelki ümmetlerin yaptığı gibi dua etmeleri gerektiği zikredilmektedir.

\footnotetext{
106 Âl-i ‘'̇mrân, 3/146.

107 Ahmed b. Muhammed el-Herevî, el-Ğerîbeyn fi'l-Kur'ân ve'l-Hadîs, thk: Ahmed Ferîd elMezîdî, Mektebetu Nizâr Mustafa el-Bâz, Riyâd 1419/1999, s. 699.

${ }^{108}$ Ahmed b. Fâris b. Zekeriyya, Mekâyîsu'l-luğa, Dâru'l-Fikr, b.y., 1399/1979, 2/382.

${ }^{109}$ Al-i 'İmrân, 3/147.

${ }^{110}$ Mâturîdî, Te'vilâtu'l-Kur'ân, II, 503.

${ }^{111}$ Mâturîdî, Te'vilâtu'l-Kur'ân, II, 503.

${ }^{112}$ Çiçek, Durûsu'l-Ed 'iyyeti'l-Kur'âniyye, s. 56.

113 İbn 'Âşûr, et-Tahrîr ve 't-Tenvîr, IV, 120.

${ }^{114}$ Mazharî, Tefsîru'l-Mazharî, II, 563.

${ }^{115}$ Çiçek, Durûsu'l-Ed 'iyyeti'l-Kur'âniyye, s. 11.

${ }^{116}$ Mâturîdî, Te'vilâtu'l-Kur'ân, II, 502.

${ }^{117}$ Mâturîdî, Te'vîlâtu'l-Kur'ân, II, 501.
} 
Zemahşerî’ye (ö. 538/1144) göre nusreti vaad etmesine rağmen ilahî yardım gerçekleşmiyorsa ve düşmanın istila etme emareleri ortaya çıkıyorsa bu, mü'minlerden kaynaklanan aksaklıkların ve onlardan sadır olan günahların varlığına delalet etmektedir. Bu durumda mü'minlerin, nusreti talep etmeden evvel tövbe ve istiğfara başvurmaları gerektiğini ifade etmektedir. ${ }^{118}$

Bu âyetle mü'minlerin küçük-büyük tüm günahlardan tövbe ettiklerini ifade eden Râzî (ö. 606/1210), daha sonra da vahim sonuçlara sebep olan isrâfin zikredildiğini, bilahare korkuyu kalplerden söken ve tehlikeleri bertaraf eden ayaklarımızı sâbit kıl ifadesinin yer aldığını ve en sonunda da ehl-i küfre karşı yardım talebinin belirtildiğini açıklamıştır. ${ }^{119}$ Râzî bu sıralamaya dikkat çekerek bundan gerekli derslerin çıkarılması gerektiğini, buna göre tavır sergilemenin ehemmiyetini vurgulamıştır.

Yukarıdaki âyette dua eden mü'minlerin, işlenen günahları kendilerine izafe etmeleri mütevazı olduklarının göstergesidir. Bu dua, taleplerini Allah'a arz etmenin, O’na karşı alçak gönüllü olma örnekliğinin ileri şekli olarak görülmektedir. ${ }^{120}$ Ayrıca âyetin başında yer alan "söyledikleri sadece..." ifadesi, onların bu duayı çokça yapmayı adet edindiklerini göstermektedir. ${ }^{121}$

Ribbiyyûn vasıflı mü'minlerin duasından bahseden âyetlerden hemen önce Uhud savaşında müşriklerin "Muhammed öldürüldü" haberi ile rehavete kapılan ve acziyet gösterenlerin, nâzil olan âyetlerle ${ }^{122}$ eleştirildikleri ve kınandıkları görülmektedir. ${ }^{123} \mathrm{Bu}$ âyetler ile söz konusu duada yer alan hususları birlikte değerlendirebilmek için Taberî'de yer alan bazı rivâyetleri maddeler hâlinde zikretmek istiyoruz:

a. Katâde'den gelen rivâyette bazı insanların "Şayet o, peygamber olsayd1, öldürülmezdi" söylemine karşın sahâbeden bazıları şöyle demişti:

"Peygamberinizin savaştığı ilkeler uğrunda siz de savaşın ki Allah da size zaferi nasip etsin ve sizi aziz k1lsın."

b. Reb'i'den gelen bir rivâyette Muhacirlerden biri Ensârdan birine "Ey falan! Muhammed'in katledildiğini duymadın mı?" deyince o, "Muhammed öldürülmüş ise şunu bilin ki o, tebliğde bulunmuştur. Öyleyse dininiz için savaşın." cevabını vermiştir. ${ }^{125}$ Ebu Nuceyh'ten gelen bir rivâyette de benzer ifadeler yer almıştır. ${ }^{126}$

c. Süddî’den gelen bir rivâyette ise okçular tepesine yerleştirilen sahâbenin durumu ve Hz. Peygamber'in yaralanması ile ilgili ayrıntılı bilgiler verildikten sonra şu ifadelere yer verilmiştir: Bazıları, “Keşke Abdullah b. Übeyy’e haber

\footnotetext{
118 Cârullah Muahmmed b. Omer b. Muhammed Zemahşerî, el-Keşşâf 'An Hakâiki Ğevâmidi'tTenzîl Ve 'Uyûni'l-Ekâvîl fî̀ Vucûhi't-Te'vîl, , Dâru'l-Kutubi'l-İlmiyye, Beyrut, 2006, II, 416.

${ }^{119}$ Râzî, Mefâtîhu'l-Ğeyb, V, 30.

${ }^{120}$ Havva, el-Esas fi't-Tefsîr, C. II, s. 889.

${ }^{121}$ Havva, el-Esas fi't-Tefsîr, C. II, s 889.

122 "Muhammed, ancak bir peygamberdir. Ondan önce de peygamberler gelip geçmiştir. Şimdi o ölür veya öldürülürse gerisingeriye (eski dininize) mi döneceksiniz? Kim gerisingeriye dönerse, Allah'a hiçbir zarar veremez. Allah, şükredenleri mükâfatlandıracaktır.” (Âl-i ‘'̇̀rân, 3/144).

123 Taberî, Câmi 'u'l-Beyân, IV, 140.

124 Taberî, Câmi 'u'l-Beyân, IV, 141.

${ }^{125}$ Taberî, Câmi 'u'l-Beyân, IV, 141.

${ }^{126}$ Taberî, Câmi 'u'l-Beyân, IV, 143.
} 
verseydik de bizi Ebu Sufyan'a karşı güvenceye alsaydı. Ey kavmim! Muhammed katledildi. Ebu Sufyan bize ulaşmadan evvel kavmimizle buluşalım. Aksi takdirde bizi de öldürecektir." demiştir. Bunun üzerine Enes b. Nadr onlara şöyle seslenmiştir: "Ey kavmim! Muhammed katledildi ise bilesiniz ki Muhammed'in Rabbi öldürülmedi. Muhammed'in uğrunda savaştı̆̆ prensipler için siz de savaşın. Ey Rabbim! Bu insanların söylemlerinden dolayı sana sığınıyorum.” Daha sonra Enes b. Nadr kılıcını çekti ve şehit oluncaya kadar savaştı. ${ }^{127}$

d. Dahhâk'tan gelen bir rivâyette Uhud savaşında kalbinde şüphe ve nifak olan insanlar, " "قتل محمد فالحقق ا بدينكم الاول / Muhammed katledildi. Öyle ise atalarınızın dinine dönün." deyince "Muhammed, ancak bir peygamberdir. Ondan önce de peygamberler gelip geçmiştir. Şimdi o ölür veya öldürülürse gerisingeriye (eski dininize) mi döneceksiniz? Kim gerisingeriye dönerse, Allah'a hiçbir zarar veremez. Allah, şükredenleri mükâfatlandıracaktır. "128 âyeti nâzil oldu. ${ }^{129}$

Yukarıdaki rivâyetleri aktaran Taberî (ö. 310/923), şu değerlendirmeyi yapmaktadır: "Yüce Allah, Uhud savaşında düşmanla karşılaşmaktan kaçınan insanları kınamakta ve onları şöyle uyarmaktadır: "Peygamberiniz katledildi" denildiğinde evvelki topluluklardan peygamberleri katledilen mü'minlerin takındığı tavrı takınmanız, onların sabrettiği gibi sabretmeniz, zafiyet göstermeden ve düşmana boyun eğmeden nusret ve zaferi Rabbinizden talep etmeniz gerekmez miydi? Unutmayınız ki, onlara zaferi nasip ettiği gibi size de nasip edecektir." 130

Yukarıdaki âyetin de yer aldığı Âl-i İmrân sûresinin 144 ile 148. âyetleri, Uhud Savaşı'nda "Abdullah b. Übey'e gidelim de Mekke şirk toplumunun lideri Ebû Süfyân'dan bizim için eman dilesin" diyen müslümanlara veya münafiklara bir uyarı ve sitem içermektedir. Çünkü bunlar bu sıkıntılı anda böyle söylerken geçmiş peygamberlerin yanında bulunan Allah erleri, başlarına gelenlerin bir hikmeti bulunduğunu veya kendilerinde var olan bir kusurdan, bir hatadan yahut aldıkları emri ve görevi gerektiği gibi yerine getirememekten cezalandırıldıklarını düşünmüşlerdir. Bundan dolayı "Rabbimiz, günahlarımızdan ve işimizdeki taşkınlığımızdan ötürü bizi bağışla!” diye dua etmiş, sonra da ehl-i küfre karşı Yüce Allah'tan sabır ve zafer dilemişlerdir. "Allah da onlara hem dünya nimetini, hem de ahiretin güzel mükâfatını verdi. Allah, güzel davrananları sever." âyetinden de anlaşıldığı üzere Yüce Allah da onların bu samimi dileklerini kabul etmiş; onlara dünya mükâfatı olarak zafer ve ganimet; âhiret sevabı olarak da güzel mükâfat nasip etmiştir. ${ }^{132}$

$\mathrm{Bu}$ duada, zorbalıklarını insanların vicdanları üzerinde baskı kurmaya kadar götüren zalimler karşısında iyilerin Allah'a güven ve bağlılıklarını, sebatkâr ve

\footnotetext{
127 Taberî, Câmi 'u'l-Beyân, IV, 141-142.

128 Âl-i 'İmrân, 3/144.

129 Taberî, Câmi 'u'l-Beyân, IV, 1413.

${ }^{130}$ Taberî, Câmi ‘u'l-Beyân, IV, 153. Ayrıca bkz. Râzî, Mefâtîhu'l-Ğeyb, V, 28.

131 Âl-i 'İmrân, 3/148.

${ }^{132}$ Hayrettin Karaman ve diğerleri, Kur'ân Yolu Türkçe Meal ve Tefsîr, DİB Yay, Ankara 2014, I, 686.
} 
yürekli tavırlarını sergilemesi bakımından anlamlı ve yol gösterici ifadeler yer almaktadır. ${ }^{133}$

Hülasa, Uhud savaşında Hz. Peygamber'in katledildiği haberi üzerine paniğe kapılan sahabeler, nazil olan âyetler silsilesi ile sert bir şekilde uyarılmıştır. $\mathrm{Bu}$ âyetlerde hak-batıl mücadelesinde hakkın tarafinı tutmanın fani olan insanların hayatı ile kaim olmaması gerektiği, peygamber de olsa Allah'ın iradesi olmadan ölümün söz konusu olmayacağı bildirilmiştir. Hemen akabinde de uhrevî hayatı dünyevî hayata tercih edenlerin övgüyle anıldığı, peygamberlerini yalnız bırakmayan ribbiyyûn vasfina sahip müminlerin gelen musibetlerden dolay1 rehavete kapılmadığı, dağılıp gitmediği ve yukarıda geçen duayı yaptığı anlaşılmıştır. Dolayısıyla bu duanın da kıssanın anlaşılmasında ne kadar etkili olduğu hususu anlaşılmaktadır.

\section{Sonuç}

Kur'ân-1 Kerîm'de geçen duaların ekseriyeti, farklı yerlerde ve değişik vesilelerle zikredilen kıssalarda geçmektedir. Toplumun dikkatini çeken dua mevzusu ile ilgili sağlıklı bilgiye ve ilgili duaları bağlamıyla birlikte anlamaya ihtiyaç duyulduğu muhakkaktır. Zira bağlam kavramı, birçok ilim dalına ait metinleri anlamada önemli bir yere sahiptir. Bu husus, dinî metinleri anlama açısından daha çok ehemmiyetlidir. Dolayısıyla Kur'ân'da zikredilen kıssaların anlaşılmasında bağlam ne kadar mühim ise söz konusu kıssalarda geçen duaları anlamak için de bağlam o kadar önemlidir.

Kur'ân'ın ana hedef ve gayelerinin Kur'ân'daki kıssalara ve kıssalardaki dualara yansıdığını ifade etmek mümkündür. Kur'ânî dualardaki bu gaye ve hedefleri anlayabilmek için de ilgili duayı bağlamı ile birlikte değerlendirmeye ihtiyaç bulunmaktadır. Bu çalışmamızda dört örnek dua seçilmiş olup bunların ilgili kıssanın anlaşılmasındaki rolü üzerinde durulmuştur. Bunlardan Hz. Şuayb ile Hz. Mûsâ kıssaları Mekkî sûrelerde; Tâlût kıssası ile ribbiyyûn kıssası ise Medenî sûrelerde zikredilmiştir. Seçilen bu dualar ile ilgili değerlendirmelerin Kur'ân'daki diğer dualara da uygulanabilirliği kanaati hâsıl olmuştur.

Toplumda baş gösteren yozlaşmaya ve ticarette hızla yayılan gayr-i ahlâkî ve hukuk dışı gelişmelere karşı toplumu uyaran Hz. Şuayb ile Firavun'a karşı tevhid mücadelesini yürüten ve üstlendiği görevin sorumluluğu ile hareket eden $\mathrm{Hz}$. Mûsâ'nın bu süreçte dua etmeyi ihmal etmedikleri hatta yaşadıkları süreci dualarına aktardıkları anlaşılmıştır. Diğer taraftan Tâlût'un şahsında topluma rehberlik edecek ehliyet sahibi şahsiyetlere ve onları yalnız bırakmayan müminlere tarih boyunca ihtiyaç duyulmuştur. Benzer şekilde tevhid mesajını sonraki nesillere aktarmak için peygamberleri yalnız bırakmayan ve ribbiyyûn olarak nitelenen mü'minlerin de başa gelen sıkıntılara ve musibetlere aldırış etmeden hakkın tarafında yer aldıkları anlaşılmıştır. Söz konusu mesajların kıssalardaki dualarda yer aldığı ve duaların da kıssaların anlaşılmasına ciddi katkı sağladığı görülmüştür.

Buna göre Kur'an kıssalarındaki duaların ilgili kıssanın zikredildiği dönemin inanç dünyası başta olmak üzere siyasî, sosyal ve ahlakî yapısı gibi temel

${ }^{133}$ Karaman vd, Kur'ân Yolu Türkçe Meal ve Tefsîr, II, 556-557. 
sorunlarına atıflar yapıldığı fark edilmiştir. Kıssalarda zikredilen dualar, söz konusu kıssanın serüvenini içermesi bakımından onların anlaşılmasına önemli katkı sağladığı görülmüştür. Bu çalışmaya esas teşkil eden dört kıssadan da anlaşıldığı üzere kıssayı duadan veya duayı kıssadan müstakil olarak "okuma"ya ve "anlama"ya çalışmak, kıssanın bütün olarak anlaşılma faaliyetini olumsuz etkileyeceği anlaşılmıştır.

\section{Kaynakça}

ABDULBAKİ, Muhammed Fuad, el-Mu'cemu'l-Mufehres li Elfâzi'l-Kur'âni'lKerîm, Dâru'l-Ma'rife, 2. Bask1, Beyrût 1411/1991.

AGİTOĞLU, Nurullah, Hadis ve Bağlam, Kitâbî Yay., İstanbul 2015.

AKBAŞ, Ahmet, Kur'ân'da İnsanın Mutluluğu, Rağbet Yayınları, İstanbul 2015.

AKPINAR, Ali, Peygamber Dualarl, Serhat Kitapevi, 5. Bask1, Konya 2009.

ALBAYRAK, Halis, Kur'ân ’ın Bütünlüğü Üzerine, Şule Yay., 1996.

AY, Mahmut, Kur'ân Kıssalarını Sîret Bağlamında Okumak, Ensar Yay., İstanbul 2017.

.............., "Kur'ân Kissalarını Hz. Muhammed'in Kıssası Paralelinde Okumak", Kur'ân Nüzĥlünün Medine Dönemi, X. Tefsir Akademisyenleri Buluşması, Kahramanmaraş 2013.

AYAN, Hidayet, Kur'ân'da Peygamber Duaları Ve Dînî Kültürümüzdeki Yeri, Marmara Üniversitesi Sosyal Bilimler Enstitüsü, İstanbul 2009, "Basılmamış Yüksek Lisans Tezi”.

AYDIN, Şükrü, “Kur’an'a Göre Yahudiliğin Misır Dönemi ve Bu Dönemdeki Bölge Halklarının Karakter Yapıları”, Uluslararası Sosyal Araştırmalar Dergisi, Cilt: 9 Sayı: 47, Aralık 2016.

BEYDÂVÎ, Nâsiruddîn 'Abdullah b. 'Omer eş-Şirâzî, Envâru't-tenzîl ve Esrâru'tTe'vîl, Dâru'l-Ma'rife, Beyrût, 1434/2013.

BİLGİÇ, Saliha, Konuları İtibarı İle Kur'an'da Dua, Selçuk Üniversitesi Sosyal Bilimler Enstitüsü, Konya 2008, "Basılmamış Yüksek Lisans Tezi”.

BULADI, Kerim, Dua'nız Olmasaydl, Kayıhan Yay., İstanbul 2013.

CABİRÎ, Muhammed 'Âbid, Fehmu'l-Kur'ân, Dâru'n-Neşril-Mağribî, Mağrib 2008.

CİLACI, Osman, "Dua", Türkiye Diyanet Vakfi İslam Ansiklopedisi, Türkiye Diyanet Vakfı yayınları, , IX, 529, 1995.

COŞKUN, Muhammed, Kur'ân Yorumunda Sîret-Nüzûl İlişkisi, Fikir Yay., İstanbul 2014.

CÜNDİOĞLU, Kur'ân'ı Anlamanın Anlamı, Tibyan Yay., İstanbul 1995.

ÇAĞLAR, Edip, “Araplarda Dua ve Yaygın Olarak Kullanılan Duaların Belăğat Açısından Değerlendirilmesi”, D.E.Ü. Illahiyat Fakültesi Dergisi, S. XVIII, s. 171, İzmir 2003.

ÇALIŞKAN, İsmail, Tefsîr Usulü, Ankara Okulu Yay., Ankara 2017. 
ÇİÇEK, Muhammed Halîl, Durûsu'l-Ed 'iyyeti'l-Kur'âniyye, Dâru'l-Kütübi'l'İlmiyye, Beyrût 2013.

DERVEZE, Muhammed İzzet, et-Tefsîru'l-Hadîs, Dâru'l-Ğarbi'l-İslâmî, Beyrût 2000.

DRAZ, Abdullah, Kur'ân'a Giriş, Kitâbiyât Yay., Ankara 2000.

ENSARİ, Abdurrahman, el-Mürşidü'l-Veciz İla Ulûmi'l-Kur'ani'l-Aziz, Nida Yayınc1lık, İstanbul 2016.

ERTUÇ, Abdullah, Kur'an'da Dua Kavramının Din Eğitimi Açısından Tahlili, Süleyman Demirel Üniversitesi Sosyal Bilimler Enstitüsü, Isparta 2012, "Basılmamış Yüksek Lisans Tezi".

ESED, Muhammed, Kur'an Mesajı, çev, Cahit Koytak, Ahmet Ertürk, İşaret Yay., İstanbul 1999.

GAZZÂLÎ, Muhammed, Fennu'z-Zikr ve'd-Du'â, Dâru'ş-Şurûk, Kâhire 2014.

GEZER, Süleyman, “Sözlü ve Yazılı Kültür Ayırımında Kur'ân”, İslâmî İlimler Dergisi, Y1l:3, S. 2, s. 249, Güz 2008.

GÜNEŞ, Abdulbaki, Kur'ân Kıssaları ve Medeniyetlerin İnşası, Gündönümü Yay, İstanbul 2005.

HAVVA, Said, el-Esas fi 't-Tefsîr, Dâru's-Selâm, 4. Tab', Kahire 1993.

HEREVÎ, Ahmed b. Muhammed, el-Ğerîbeyn fi'l-Kur'ân ve'l-Hadîs, thk: Ahmed Ferîd el-Mezîdî, MEktebetu Nizâr Mustafa el-Bâz, Riyâd 1419/1999.

HİCÂZÎ, Târık b. 'Atıf, el-Câmi'u'l-'Amme fi'l-Ed'iyye ve'l-Ezkâr, Dâru'lMevedde, Kâhire 1435.

HÖKELEKLİ, Hayati, Din Psikolojisi, TDV Yay, Ankara 1996.

IZUTSU, Toshihiko, Kur'ân'da Allah ve İnsan, çev. Süleyman Ateş, Kevser Yay., Ankara ts.

İBN ‘ÂŞÛR, Muhammed et-Tahir, et-Tahrîr ve’t-Tenvîr, Dâr Suhnûn, Tûnus ts.

İBN FÂRİS, Ahmed b. Zekeriyya, Mekâyîsu'l-luğa, Dâru'l-Fikr, b.y., 1399/1979, $2 / 382$.

İBN MANZÛR, Lisânü'l-'Arab, “Da'â" md.

İSFEHÂNÎ, Râğib, el-Mufredât fî Ğarîbi'l-Kur'ân, Thk: Muhammed Seyyid Keylânî, Dâru'l-Ma'rife, Beyrut trs.

KARAMAN, Hayrettin vd., Kur'ân Yolu Türkçe Meal ve Tefsîr, DİB Yay, Ankara 2014.

KAYIKLIK, Hasan, “Kur'ân'daki Dualar Üzerine Psikolojik Bir Değerlendirme”, Çukurova Üniv. Ilahiyat Fak Dergisi, S.1, C. 1, s. 136, 2001.

KASTALÂNî, Muhammed Şihâbuddin, Levâmi 'u'l-Envâr fi'l-Ed 'iye ve'l-Ezkâr, Dâr İbn Hazm, 1437/2016.

KURTUBÎ, Muhammed b. Ahmed, el-Câmi“ li Ahkâmi'l-Kur'ân, Dâru'l-Fikr, Beyrût 1415/1995. 
MÂTURÎDÎ, Muhammed b. Muhammed, Te'vilâtu'l-Kur'ân, thk: Mecdî Bâsellûm, Dâru'l-Kutubi'l-İlmiyye, Beyrût, 2005

MEVDUDİ, Ebu'l-A'lâ, Tefhimu'l-Kur'ân, çev: Kurul, İnsan Yay., İstanbul 1991.

MAZHARÎ, Muhammed Senâullah, Tefsîru'l-Mazharî, Mektebetu Reşîdiyye, trs b.y.

NECATI, M. Osman, Kur'ân ve Psikoloji, Çev: Hayati Aydın, Fecr Yayınları, Ankara 2017.

NEVEVÎ, Yahya b. Şeref, el-Ezkâr, Dâru'l-Feyhâ', Dimaşk 1438/2017.

PEKCAN, Ali, Dualar ve Zikirler, Ek Kitap Yay., İstanbul 2012.

RÂZÎ, Fahruddîn, Mefâtîhu'l-Ğeyb: et-Tefsîru'l-Kebîr, Dâru'l-Fikr, Beyrut 2005.

SERINSU, Ahmet Nedim, Kur'ân ve Bağlam, Şule Yay., İstanbul 2012.

SIRMA, İhsan Süreyya, Müslümanların Tarihi, Beyan Yay., İstanbul 2016.

ŞERİATİ, Ali, Dua, Fecr Yay., Ankara 2013.

ŞİMŞEK, Mehmet Sait, Hayat Kaynăğ Kur'ân Tefsiri, Beyan Yay., İstanbul 2012.

TABERÎ, Muhammed b. Cerîr, Câmi 'u'l-Beyân 'An Te'vîli Âyi'l-Kur'ân, Dâr İbn Hazm, Beyrut 2002.

TABERÎ, Suleyman b. Ahmed, Kitâbu'd-Du‘â, Dâru'l-Hadîs, Kâhire 1428/2007.

TEMIZER, Aydın, Kur'ân Tefsîrinde Karine, İfav Yay., 2. Baskı, İstanbul 2016.

TIYYK, Fatih, Kur'an'ı Anlamada Bağlamın Rolü ve Meallerdeki Bağlamsal Sorunlar, Ankara Okulu Yay., Ankara 2015.

UZUN, Nihat, Bağlam ve Kur'ân'ın Anlaşılması Üzerine, Ankara Okulu Yay., Ankara 2016.

YARGICI, Atilla Kur'ân'da Dua, İltek Yay., İstanbul 2017.

ZEMAHŞERÎ, Cârullah Muahmmed b. Ömer b. Muhammed, el-Keşşâf 'An Hakâiki Ğevâmidi't-Tenzîl Ve 'Uyûni'l-Ekâvîl fî̀ Vucûhi't-Te'vîl, Dâru'l-Kutubi'lİlmiyye, Beyrut 2006. 